\title{
Does Vitamin D Level Affect the Response to Antiviral Treatment in Egyptian Patients with Chronic Hepatitis C?
}

\author{
Kronik Hepatit C'li Mısırlı Hastalarda D Vitamini Düzeyi Antiviral Tedavi Cevabını Etkiler mi?
}

\author{
Hoda Abdelbadie HUSSEIN1, Hany Badreldin MOHAMAD2, Mohamad Abdelhadi MASHAHEET1, \\ Maher Abubakr ALAMIR1', Ghada Mohamad EZZAT3
}

${ }^{1}$ Fayoum University Faculty of Medicine, Department of Internal Medicine, Fayoum, Egypt

2Fayoum General Hospital, Department of Hepatology, Fayoum, Egypt

3 Fayoum University Faculty of Medicine, Department of Clinical Pathology, Fayoum, Egypt

\begin{abstract}
Objective: Vitamin D deficiency is common in patients with chronic liver disease. Several studies demonstrated that its levels are inversely related to the disease severity and documented improvement of the disease following supplementation especially regarding to hepatitis $\mathrm{C}$ virus $(\mathrm{HCV})$ infection. To study level of vitamin D in Egyptian patients with chronic HCV infection and to investigate its correlation with activity and fibrosis scores of their liver biopsies, as well as the relationship of vitamin D levels with patients' response to antiviral therapy.

Materials and Methods: The study included 60 Egyptian patients with chronic HCV infection who were scheduled for antiviral medications (pegylated-interferon and ribavirin) for 48 weeks and 50 healthy age- and sex-matched individuals non-reactive for HCV antibodies as a control group. Serum 25-hydroxyvitamin D was measured in all patients and controls and compared with patients' liver biopsy results and their virological response (after 48 weeks treatment) assessed by polymerase chain reaction for $\mathrm{HCV}$.

Results: Serum vitamin D levels were inversely correlated with activity and fibrosis scores in liver biopsy. On the other hand, $63.3 \%$ of cases had good response to interferon treatment and $36.7 \%$ of them had no response without significant difference in serum vitamin $D$ levels between responders and non-responders $(39.2 \pm 23.6$ and $37.1 \pm 13.2 \mathrm{ng} / \mathrm{mL}$, respectively).

Conclusion: Vitamin D levels could affect liver necro-inflammatory process in Egyptian patients with chronic hepatitis $\mathrm{C}$ infection, but did not show significant effect on response to antiviral therapy. Keywords: Chronic hepatitis $\mathrm{C}$, virological response, vitamin D
\end{abstract}

ÖZ

Amaç: Kronik karaciğer hastalığı olanlarda D vitamini eksikliği yüksek prevalans göstermektedir. D vitamini düzeyleri hastalığın şiddeti ile ters ilişki göstermektedir. Girişimsel çalışmalar suplemantasyon sonrası kronik karaciğer hastalığında iyileșme raporlamaktadır. Benzer şekilde hepatit $C$ virüs (HCV) enfeksiyonuna ilişkin sağlık durumunda düzelme bildirilmiştir. Kronik HCV enfeksiyonu olan Mısırlı hastalardaki vitamin D düzeyini belirlemek ve vitamin düzeyi ile karaciğer biyopsisi aktivite ve fibrozis skorları arasındaki ilişkiyi araștırmak, ayrıca antiviral tedaviye hastanın cevabı ile ilișkisini incelemektir.

Gereç ve Yöntemler: Bu çalışma kronik HCV enfeksiyonu olan 60 Mısırlı hastada gerçekleştirilmiştir. Bu hastalar 48 hafta antiviral tedavi (pegile-interferon ve ribavirin) almıştır. Yaş ve cinsiyet uyumlu, HCV antikorları açısından reaktif olmayan 50 sağlıklı kişi de kontrol grubunu oluşturmuştur. Serum 25 hidroksivitamin D hem hastalar, hem de kontrol grubunda ölçülmüştür. Sonuçlar hastaların karaciğer biyopsi sonuçları ve HCV polimeraz zincir reaksiyonu ile değerlendirilen virolojik cevapları (48 haftalık tedavi sonrası) ile karşılaştırılmıştır. Bulgular: Serum D vitamini düzeyleri karaciğer biyopsisi aktivite ve fibrozis skorları ile ters ilişkili bulunmuştur. Olguların \%63,3'ü interferon tedavisine iyi yanıt vermiştir. Tedaviye cevap ile vitamin D düzeyi ilişkisi ise korele bulunmamıştır (Tedaviye cevap veren ve vermeyen olgulardaki $D$ vitamin düzeyi ortalamaları sırasıyla $39,2 \pm 23,6 \mathrm{ng} / \mathrm{mL}, 37,1 \pm 13,2 \mathrm{ng} / \mathrm{mL}$ ).

Sonuç: Kronik hepatit $C$ enfeksiyonlu Mısırlı hastalarda D vitamini düzeyleri karaciğerin nekro-enflamatuvar süreçlerini etkilemiştir, ancak antiviral tedaviye cevap üzerinde anlamlı etkisi olmamıștır. Anahtar Kelimeler: Kronik hepatit C, virolojik cevap, D vitamini

Hussein HA, Mohamad HB, Mashaheet MA, Alamir MA, Ezzat GM. Does Vitamin D Level Affect the Response to Antiviral Treatment in Egyptian Patients with Chronic Hepatitis C? Viral Hepat J. 2017;23:50-54. 


\section{Introduction}

Vitamin D plays a central role in calcium and phosphate homeostasis and is essential for the proper development and maintenance of bone. It is also known to be involved in cell proliferation, differentiation, and immunomodulation (1). Vitamin D (D3 and D2) is hydroxylated in the liver to 25-hydroxyvitamin D $[25(\mathrm{OH}) \mathrm{D}]$ and secreted in the circulation, again, mostly bound to vitamin D binding protein (DBP). DBP is synthesized in the liver. It represents a biomarker for severe liver disease (2).

An association between serum vitamin $D$ level and chronic liver disease (CLD) has also been described $(3,4)$. In their review, Stokes et al. (2) stated that the prevalence of vitamin D levels $<20$ $\mathrm{ng} / \mathrm{mL}$ in CLD has been reported to range from 64 to $92 \%$ and was commonly inversely related to disease progression. Some studies showed no difference in vitamin $D$ levels between patients with cirrhosis and patients without cirrhosis (5). Bitetto et al. (6) showed that a lower level of vitamin $D$ is associated with a higher inflammatory grade and more advanced stage of fibrosis.

The aim of treatment is to cure hepatitis $\mathrm{C}$ virus (HCV) infection, to prevent the complications of chronic hepatitis $\mathrm{C}$ including liver cirrhosis, hepatocellular carcinoma, severe extra-hepatic complications and death. The goal of treatment is a sustained viral response (SVR), defined by undetectable HCV RNA in blood 12 weeks or 24 weeks (SVR24) after the end of treatment. The HCV genotype and genotype 1 subtype (1a or $1 \mathrm{~b}$ ) and baseline virological parameters that will be useful for tailoring therapy must be evaluated before starting treatment (7). In some studies, lower rates of SVR in HCV patients undergoing interferon-based therapy were detected to be associated with vitamin D deficiency $(8,9)$. Other studies concluded that vitamin D replacement could improve the response to antiviral therapy in patients with chronic hepatitis $\mathrm{C}$ and increase the percentage of SVR $(10,11)$.

Corey et al. (12) studied the effect of vitamin D levels on the progression of CLD through four years follow-up. They found no effect of vitamin $D$ deficiency on disease progression. A recent Brazilian retrospective study documented that there was no relationship between vitamin D status, stage of liver fibrosis, and treatment response to interferon and ribavirin in patients with chronic hepatitis C (13). Accordingly, the relationship of serum vitamin $D$ levels with both grade of liver inflammation and stage of fibrosis and virological response in patients with chronic hepatitis $\mathrm{C}$ remains controversial, and further research on Egyptian patients is required.

\section{Materials and Methods}

All the study steps were explained to all the participants, and informed consent was obtained from all of them. The study was conducted after approval of the Ethics Committee of Faculty of Medicine Fayoum University. Our study was conducted on 110 Egyptian participants: 60 patients with chronic HCV infection who were scheduled for antiviral therapy (pegylated-interferon combined with ribavirin according to the official protocol of the Egyptian Ministry of Health irrespective of HCV genotype) for 48 weeks at the Hepatology Unit at Fayoum General Hospital, and 50 healthy age- and sex-matched individuals, non-reactive for $\mathrm{HCV}$ antibodies as controls.
Patients with malnutrition, malabsorption or renal failure and those on drugs affecting vitamin D levels, such as calcium or vitamin D supplementation, were excluded.

The results of polymerase chain reaction (PCR) for detecting HCV RNA before treatment and 24 weeks after completion of treatment to assess SVR (SVR24 means undetectable HCV-RNA at 24 weeks after the end of treatment) recorded from their files. Plasma HCV-RNA levels were measured using the COBAS TaqMan HCV assay, version 1.0 (Roche Molecular Systems), with a lower limit of quantification of $35-45 \mathrm{lU} / \mathrm{mL}$ and a lower limit of detection of $10 \mathrm{lU} / \mathrm{mL}$. Therefore, the total duration of the study was about 1.5 years.

Pretreatment serum 25(OH)D levels were assessed in patients and controls. The DRG 25(OH)D Total enzyme-linked immunosorbent assay (ELISA) Kit is a solid phase ELISA based on the competitive principle for measurement of total $25(\mathrm{OH}) \mathrm{D}$ (vitamin D2 and vitamin D3). Accordingly, 25(OH)D levels were classified into three states: deficient - $\leq 10 \mathrm{ng} / \mathrm{mL}$, insufficient -11$30 \mathrm{ng} / \mathrm{mL}$, and optimal - $>30 \mathrm{ng} / \mathrm{mL}$.

The results of liver biopsy performed for histopathological analysis of fibrosis stage and degree of necroinflammatory activity and exclusion of other causes of CLD were recorded from their files. Biopsy specimen were evaluated for the grade of inflammation and stage of fibrosis using the Metavir system. Inflammatory activity was graded from A0 to A3 and the stage of liver fibrosis and architectural disturbances ranged from F0 to F4 (14).

SPSS software version 18 was used for statistical analysis. Simple descriptive qualitative data were expressed in the form of numbers and percentages. In quantitative analysis of data; we used standard deviation for dispersion, t-test to compare two independent groups and One-Way ANOVA test in comparing more than two independent groups. Comparison of two of more qualitative groups was assessed by chi-square test. A p level of $\leq 0.05$ was considered statistically significant.

\section{Results}

This study included 60 patients with chronic HCV infection (32 males and 28 females) with an age mean of $46 \pm 8$ years. Fifty healthy individual with age mean of $43 \pm 10.3$ years, non-reactive for HCV antibodies, constituted the control group (18 males and 32 females). Nine patients in the patients group had diabetes mellitus. Table 1 illustrates the characteristics of the studied patients before antiviral treatment. The mean alanine aminotransferase (ALT) level was $62.2 \pm 33.1 \mathrm{IU} / \mathrm{L}$, aspartate aminotransferase (AST) level - 54.6 $\pm 27.2 \mathrm{IU} / \mathrm{L}$, PCR level - 576.039 $\pm 1.025 .556 \mathrm{IU} / \mathrm{mL}$ and the mean serum vitamin D level was $36.4 \pm 16.9 \mathrm{ng} / \mathrm{mL}$. According to the results of the liver biopsy performed in 60 patients, 35 (58.4\%) subjects had inflammatory activity grade A1, 23 (38.3\%) - grade A2 and two (3.3\%) had grade A0, while 23 (38.4\%) had fibrosis stage F2, 20 (33.3\%) - F1, and 17 (28.3\%) patients had F3. Thirtyeight subjects (63.3\%) had good SVR to interferon treatment and $22(36.7 \%)$ had no response. There was no significant difference in vitamin $\mathrm{D}$ levels between patients and controls (36.4 \pm 16.9 and $34.9 \pm 16 \mathrm{ng} / \mathrm{mL}$, respectively; $\mathrm{p}=0.3$ ).

There was no significant correlation of serum vitamin $D$ level with age, ALT, AST, and PCR (p>0.05) (Table 2). 
Table 3 shows a comparison of serum levels of vitamin D according to liver biopsy activity and fibrosis scores. It showed a significant inverse correlation $(p=0.05)$. The lowest mean vitamin $\mathrm{D}$ level (33.4 ng/mL) was detected in grade A2 activity and (31 ng/ $\mathrm{mL})$ and stage $\mathrm{F} 3$ fibrosis, followed by $(40 \mathrm{ng} / \mathrm{mL})$ grade A1 activity and (36 ng/mL) stage F2 fibrosis. The highest mean vitamin D leve was detected in grade $\mathrm{A} 0$ activity $(68 \mathrm{ng} / \mathrm{mL})$ and stage $\mathrm{F} 1$ fibrosis (47 ng/mL).

The mean vitamin $D$ level in responder and non-responder groups was $39.2 \pm 23.6$ and $37.1 \pm 13.2$, respectively and the difference was not statistically significant $(p=0.7)$ (Table 4).

\begin{tabular}{|c|c|}
\hline Variable & Result \\
\hline Age (years) & $46 \pm 8$ \\
\hline \multicolumn{2}{|l|}{ Gender } \\
\hline Male & $32(53 \%)$ \\
\hline Female & $28(47 \%)$ \\
\hline Diabetes mellitus & $9(15 \%)$ \\
\hline AST (IU/L) mean & $54.6 \pm 27.2$ \\
\hline ALT (IU/L) mean & $62.2 \pm 33.1$ \\
\hline HCV RNA (IU/mL) mean & $576.039 \pm 1.025 .556$ \\
\hline \multicolumn{2}{|l|}{ Liver biopsy activity } \\
\hline $\mathrm{A} 0$ & $2(3.3 \%)$ \\
\hline A1 & $35(58.4 \%)$ \\
\hline A2 & $23(38.3 \%)$ \\
\hline \multicolumn{2}{|l|}{ Liver biopsy fibrosis } \\
\hline F1 & $20(33.3 \%)$ \\
\hline F2 & $23(38.4 \%)$ \\
\hline F3 & $17(28.3 \%)$ \\
\hline Serum vitamin $D$ level $(\mathrm{ng} / \mathrm{mL})$ mean & $\begin{array}{l}36.4 \pm 16.9 \\
\text { (control } 34.9 \pm 16 \text { ) }\end{array}$ \\
\hline Males versus females & $\begin{array}{l}42.7 \pm 22.2,32 \pm 13 \\
(p v=0.002)\end{array}$ \\
\hline \multicolumn{2}{|l|}{ Virological response frequency } \\
\hline Responders & $38(63.3 \%)$ \\
\hline Non-responders & $22(36.7 \%)$ \\
\hline \multicolumn{2}{|c|}{$\begin{array}{l}\text { A0/A1/A2: Grades of activity, F0/F1/F2: Stages of fibrosis, pv: Probability } \\
\text { value, ALT: Alanine aminotransferase, AST: Aspartate aminotransferase, } \\
\text { HCV: Hepatitis C virus }\end{array}$} \\
\hline
\end{tabular}

Table 2. Correlation between serum level of vitamin $D$ and different study variables among cases of chronic hepatitis $C$ virus infection

\begin{tabular}{|l|l|l|l|}
\hline \multirow{2}{*}{ Variables } & \multicolumn{3}{|c|}{ Vitamin D level (ng/mL) } \\
\cline { 2 - 4 } & $\mathbf{R}$ & $\mathbf{p}$ value & Sig. \\
\hline Age (years) & 0.078 & 0.6 & NS \\
\hline ALT & 0.043 & 0.7 & NS \\
\hline AST & 0.07 & 0.6 & NS \\
\hline HCV-PCR & -0.12 & 0.4 & NS \\
\hline $\begin{array}{l}\text { Sig.: Significance, R: Linear correlation coefficient, NS: Non significant, } \\
\text { ALT: Alanine aminotransferase, AST: Aspartate aminotransferase, HCV: } \\
\text { Hepatitis C virus, PCR: Polymerase chain reaction }\end{array}$ \\
\hline
\end{tabular}

\begin{tabular}{|c|c|c|c|}
\hline \multirow[t]{2}{*}{ Variables $(n=60)$} & Level of vitamin D & \multirow[t]{2}{*}{$\mathrm{p}$ value } & \multirow[t]{2}{*}{ Sig. } \\
\hline & Mean \pm SD & & \\
\hline \multicolumn{4}{|c|}{ Liver biopsy activity } \\
\hline$A 0(n=2)$ & $68 \pm 36.8$ & \multirow{3}{*}{0.05} & \multirow{3}{*}{$\mathrm{S}$} \\
\hline$A 1(n=35)$ & $40.1 \pm 17.4$ & & \\
\hline$A 2(n=23)$ & $33.4 \pm 21.7$ & & \\
\hline \multicolumn{4}{|c|}{ Liver biopsy fibrosis } \\
\hline $\mathrm{F} 1(\mathrm{n}=20)$ & $47.1 \pm 23.1$ & \multirow{3}{*}{0.05} & \multirow{3}{*}{$\mathrm{S}$} \\
\hline$F 2(n=23)$ & $36 \pm 10.1$ & & \\
\hline F3 $(n=17)$ & $31.6 \pm 24.5$ & & \\
\hline
\end{tabular}

Table 4. Comparisons of serum level of vitamin D in chronic hepatitis $C$ patients subgroups according to response to interferon

\begin{tabular}{|l|l|l|l|}
\hline \multirow{2}{*}{ Response to interferon $(\mathbf{n}=60)$} & $\begin{array}{l}\text { Level of vitamin D } \\
(\mathbf{n g} / \mathrm{mL})\end{array}$ & p value & Sig. \\
\cline { 2 - 3 } & Mean \pm SD & & \\
\hline Non-responders $(\mathrm{n}=22)$ & $37.1 \pm 13.2$ & \multirow{2}{*}{0.7} & NS \\
\hline Responders $(\mathrm{n}=38)$ & $39.2 \pm 3.6$ & & \\
\hline Sig.: Significant, NS: Non significant & \multicolumn{3}{|l}{} \\
\hline
\end{tabular}

\section{Discussion}

In the present study, the mean serum vitamin D level was $36.4 \pm 16.9 \mathrm{ng} / \mathrm{mL}$ in patients and $34.9 \pm 16 \mathrm{ng} / \mathrm{mL}$ in controls with no statistically significant difference. Miroliaee et al. (15) demonstrated that cirrhotic patients had lower vitamin D levels than non-cirrhotic patients. Lower vitamin $D$ levels were detected in patients with Child-Pugh class B and C compared to those with class $A(p<0.001)$ while the difference in levels of serum vitamin $D$ between healthy controls and non-cirrhotic patients was not significant $(95.28 \pm 29.41$ and $81.37 \pm 30.44 \mathrm{nmol} / \mathrm{L}$, respectively). Chen et al. (16) compared vitamin $D$ levels between cirrhotic patients (various etiologies) and controls and found no significant difference in $25(\mathrm{OH}) \mathrm{D}$ levels between patients and controls, while there was a significant difference in $25(\mathrm{OH}) \mathrm{D}$ between patients with Child-Pugh class B and $\mathrm{C}$ and controls.

Conversely, Lange et al. (9) reported significantly lower levels of serum vitamin $\mathrm{D}$ in patients with chronic $\mathrm{HCV}$ infection than in those negative for HCV $(p<0.00001)$. Petta et al. (8) showed that the prevalence of $25(\mathrm{OH}) \mathrm{D}<30 \mathrm{ng} / \mathrm{mL}$ among $\mathrm{HCV}$ genotype 1 Italian patients was $73 \%$ of while it was $6 \%$ in controls $(p<0.001)$. A Spanish study (5) concluded that the prevalence of $25(\mathrm{OH}) \mathrm{D}$ $<20 \mathrm{ng} / \mathrm{mL}$ was detected in $64 \%$ of CLD patients with cirrhosis when compared with controls. Therefore, in the current study, the non-significant difference in serum vitamin $\mathrm{D}$ levels between patients and healthy control can be explained by the absence of decompensated cirrhosis in our selected cases.

Regarding virological response to $\mathrm{HCV}$ antiviral therapy in the current study, 38 (63\%) of cases had SVR24 to interferon combined with ribavirin therapy and 22 (36.7\%) had no response. These results are in agreement with other studies $(17,18,19)$ on 
the treatment of patients with chronic HCV genotype 4 (pegylatedinterferon and ribavirin) for 48 weeks. Correlation of serum levels of vitamin D grades of activity and stages of fibrosis in patients' subgroups according to liver biopsy showed significant difference. The lowest mean level of vitamin D, $33.4 \mathrm{ng} / \mathrm{mL}$ was among patients with grade $A 2$ activity and $31 \mathrm{ng} / \mathrm{mL}$ in those with stage F3 fibrosis, followed by $40 \mathrm{ng} / \mathrm{mL}$ in subjects with grade A1 activity and $36 \mathrm{ng} / \mathrm{mL}$ among patients with stage F2 fibrosis, while the highest mean level of vitamin $D, 68 \mathrm{ng} / \mathrm{mL}$ was among patients with grade $A 0$ activity and $47 \mathrm{ng} / \mathrm{mL}$ among those with stage F1 fibrosis. Comparison of vitamin D categories (sufficient and insufficient) showed highly significant difference with higher percentage of patients with insufficient vitamin D level: 14 (66\%) patients with grade A2 activity and 13 (61.9\%) patients with stage F3 fibrosis followed by 7 (33.3\%) patients with grade A1 activity and $6(28 \%)$ patients with stage F2 fibrosis.

Similar results were showed by Bitetto et al. (6) who concluded that the grade of inflammation and stage of fibrosis were inversely correlated with serum vitamin D levels. Additionally, 25(OH)D serum concentrations were inversely correlated with stage of fibrosis in patients with genotype 1 chronic hepatitis $C$ in another study done by Petta et al. (8). Other studies demonstrated the lower serum vitamin $D$ levels, the higher the degree of inflammation and/or stage of fibrosis in chronic HCV patients $(15,20,21,22)$. Arteh et al. (23) reported that vitamin $\mathrm{D}<32 \mathrm{ng} / \mathrm{mL}$ was detected in $92 \%$ of 118 patients with CLD. Another study (24) reported that $91 \%$ of patients with non-cholestatic CLD had inadequate 25(OH)D levels $(<32 \mathrm{ng} / \mathrm{mL}), 68 \%$ of them had vitamin D-deficiency $(<20 \mathrm{ng} / \mathrm{mL})$.

These findings may be explained by the role of vitamin $D$ in immune system. Deluca and Cantorna (25) demonstrated that vitamin $D$ was important in immune system, either innate or $T$ cell-mediated immunity. Vitamin $D$ affects the adaptive immune response through regulation of $\mathrm{T}$ and $\mathrm{B}$ lymphocytes, cytokines release and production of immunoglobulin (26). El Husseiny et al. (27) assessed the relationship between vitamin D and markers of inflammation in Egyptian HCV-infected patients and found a negative correlation between vitamin D and interleukin (IL)-17, IL23 and macrophage chemoattractant protein 1.

In the present study, comparisons of serum level of vitamin D in chronic hepatitis $C$ patients' subgroups according to response to interferon showed no significant difference between treatment responders and non-responders.

A recent Brazilian study (13) included 201 chronic HCV patients. $47 \%$ of patients had SVR. $69 \%$ of patients had low $25(\mathrm{OH}) \mathrm{D}$ levels $(<30 \mathrm{ng} / \mathrm{dL})$. The deficiency was not associated with stage of fibrosis or grade of inflammation. $49 \%$ of patients with vitamin D deficiency had SVR, while $40 \%$ of patients with adequate vitamin D had SVR with no statistically significance. Kitson et al. (22) reported that chronic $\mathrm{HCV}$ patients with high activity grade had lower vitamin D levels (21\% vs. $11 \% ; p=0.03$ ). In their study the mean $25(\mathrm{OH}) \mathrm{D}$ level had no correlation with the score of fibrosis or activity. A meta-analysis in 2014 (28) included 11 related studies comprising 2605 patients. The analysis reported that there was no significant association between the pretreatment mean $25(\mathrm{OH}) \mathrm{D}$ level and SVR in different viral genotypes.

Conversely, other studies concluded significant correlation between serum vitamin $\mathrm{D}$ levels and virological response to
HCV antiviral therapy $(10,29,30)$. An Italian study retrospectively evaluated $206 \mathrm{HCV}$ patients treated with pegylated-interferon and ribavirin. The authors reported that a baseline level of vitamin $\mathrm{D}>20 \mathrm{ng} / \mathrm{mL}$ strongly predicted the achievement of SVR (29). Another study (30) investigated 117 consecutive patients with chronic HCV patients genotype 1 evaluated by biopsy. Serum vitamin D levels and IL28B polymorphisms were evaluated. The patients received antiviral therapy with interferon and ribavirin. The authors reported that serum 25(OH)D levels and IL28B status were associated with higher percentages of both rapid and SVR. The results are still conflicting, may be due to different ethnicity and different disease course between populations.

\section{Study Limitations}

Limitations of the current study include absence of virus genotype assessment and lack of seasonal consideration of vitamin D measurement. Vitamin D supplementation for insufficient group could have an impact on the results.

\section{Conclusion}

In conclusion, the present study showed that vitamin D levels can affect chronic HCV progression in Egyptian patients but did not prove its association with patients' response to antiviral therapy.

\section{Ethics}

Ethics Committee Approval: The study was conducted after approval of the Ethics Committee of Faculty of Medicine Fayoum University.

Informed Consent: It was taken.

Peer-review: Externally and internally peer-reviewed.

\section{Authorship Contribution}

Surgical and Medical Practices: H.A.H., H.B.M., Concept: H.A.H., M.A.A., Data Collection or Processing: H.B.M., G.M.E., Analysis or Interpretation: G.M.E., M.A.M., H.B.M., H.A.H., Literature Search: M.A.A., M.A.M., H.A.H., Writing: H.A.H., H.B.M.

Conflict of Interest: The authors declared that there was no conflict of interest.

Financial Disclosure: The authors declared that this study received no financial support.

\section{References}

1. Gal-tanamy M, Bachmetov L, Ravid A, Koren R, Erman A, Tur-Kaspa R, Zemel R. Vitamin D: an innate antiviral agent suppressing hepatitis $\mathrm{C}$ virus in human hepatocytes. Hepatology. 2011;:54:1570-1579.

2. Stokes CS, Volmer DA, Grunhage F, Lammert F. Vitamin D in chronic liver disease. Liver Int. 2013;33:338-352.

3. Schiefke I, Fach A, Wiedmann M, Aretin AV, Schenker E, Borte G, Wiese $M$, Moessner J. Reduced bone mineral density and altered bone turnover markers in patients with non-cirrhotic chronic hepatitis B or C infection. World J Gastroenterol. 2005;11:18431847.

4. Malham M, Jørgensen SP, Ott P, Agnholt J, Vilstrup H, Borre $M$, Dahlerup JF. Vitamin D deficiency in cirrhosis relates to liver dysfunction rather than aetiology. World J Gastroenterol. 2011;17:922-925 
5. Monegal A, Navasa M, Guañabens N, Peris P, Pons F, Martinez de Osaba MJ, Rimola A, Rodés J, Muñoz-Gómez J. Osteoporosis and bone mineral metabolism disorders in cirrhotic patients referred for orthotopic liver transplantation. Calcif Tissue Int. 1997;60:148-154.

6. Bitetto D, Fattovich G, Fabris C, Ceriani E, Falleti E, Fornasiere E, Pasino M, leluzzi D, Cussigh A, Cmet S, Pirisi M, Toniutto P. Complementary role of vitamin $\mathrm{D}$ deficiency and the interleukin28B rs12979860 C/T polymorphism in predicting antiviral response in chronic hepatitis C. Hepatology. 2011;53:11181126.

7. European Association for the Study of the Liver. Electronic address: easloffice@easloffice.eu. EASL Recommendations on Treatment of Hepatitis C 2016. J Hepatol. 2017;66:153-194.

8. Petta $\mathrm{S}$, Cammà $\mathrm{C}$, Scazzone $\mathrm{C}$, Tripodo $\mathrm{C}$, Di Marco V, Bono A, Cabibi D, Licata G, Porcasi R, Marchesini G, Craxí A. Low vitamin $D$ serum level is related to severe fibrosis and low responsiveness to interferon-based therapy in genotype 1 chronic hepatitis C. Hepatology. 2010;51:1158-167.

9. Lange CM, Bojunga J, Ramos-Lopez E, von Wagner M, Hassler A, Vermehren J, Herrmann E, Badenhoop K, Zeuzem S, Sarrazin C. Vitamin D deficiency and a CYP27B1-1260 promoter polymorphism are associated with chronic hepatitis $C$ and poor response to interferon-alfa based therapy. J Hepatol. 2011;54:887893.

10. Bitetto D, Fabris C, Fornasiere E, Pipan C, Fumolo E, Cussigh A, Bignulin S, Cmet S, Fontanini E, Falleti E, Martinella R, Pirisi $\mathrm{M}$, Toniutto P. Vitamin D supplementation improves response to antiviral treatment for recurrent hepatitis C. Transpl Int 2011;24:4350.

11. Abu Mouch S, Fireman Z, Jarchovsky J, Assy N. Vitamin D supplement improves SVR in chronic hepatitis C (genotype 1) naive patients treated with PEG interferon and ribavirin. J Hepatol. 2010;52:23-41.

12. Corey KE, Zheng $H$, Mendez-Navarro J, Delgado-Borrego $A$, Dienstag JL, Chung RT; HALT-C Trial Group. Serum vitamin $D$ levels are not predictive of the progression of chronic liver disease in hepatitis $C$ patients with advanced fibrosis. PLoS ONE. 2012; 7:e27144

13. de Almeida Borges PS, Guimarães VM, de Farias JLR, Trindade LZ, El Bacha IAH, Carvalho-Filho RJ, Parise ER. Absence of Relationship between Serum Vitamin D Levels, Degree of Hepatic Fibrosis, and Virologic Response to Pegylated Interferon and Ribavirin Therapy in Patients with Chronic Hepatitis C. Journal of GHR. 2016;5:2015-2020.

14. Bedossa P, Poynard T. An algorithm for the grading of activity in chronic hepatitis C. The Metavir Cooperative Study Group. Hepatology. 1996;24:289-293.

15. Miroliaee A, Nasiri-Toosi M, Khalilzadeh O, Esteghamati A, Abdollahi A, Mazloumi M. Disturbances of parathyroid hormonevitamin $D$ axis in noncholestatic chronic liver disease: a crosssectional study. Hepatol Int. 2010;4:634-640.

16. Chen CC, Wang SS, Jeng FS, Lee SD. Metabolic bone disease of liver cirrhosis: Is it parallel to the clinical severity of cirrhosis? J Gastroenterol Hepatol. 1996;11:417-421.
17. Kamal S. Hepatitis C virus genotype 4 therapy: progress and challenges. Liver Int. 2011;31(Suppl 1):45-52.

18. Khattab MA, Eslam M, Shatat M, Abd-Aalhalim H, Mousa YI, Samir F, Aly H, Shaker O, Shaker Y. Changes in adipocytokines and insulin sensitivity during and after antiviral therapy for hepatitis $C$ genotype 4. J gastrointestin Liver Dis. 2012;21:59-65.

19. Papastergiou V, Dimitroulopoulos D, Skorda L, Lisgos P, Ketikoglou I, Kostas N, Karatapanis S. Predictors of sustained virological response in Greek and Egyptian patients with hepatitis C genotype 4: does ethnicity matter? J Med Virol. 2012;84:12171223.

20. Baur K, Mertens JC, Schmitt J, Iwata R, Stieger B, Eloranta JJ, Frei P, Stickel F, Dill MT, Seifert B, Ferrari HA, von Eckardstein A, Bochud PY, Müllhaupt B, Geier A; Swiss Hepatitis C Cohort Study Group. Combined effect of 25-OH vitamin D plasma levels and genetic Vitamin D Receptor (NR 1/1) variants on fibrosis progression rate in HCV patients. Liver Int. 2012;32:635-643.

21. Putz-Bankuti C, Pilz S, Stojakovic T, Scharnagl H, Pieber TR, Trauner M, Obermayer-Pietsch B, Stauber RE. Association of 25-hydroxyvitamin D levels with liver dysfunction and mortality in chronic liver disease. Liver Int. 2012;32:845-851.

22. Kitson MT, Dore GJ, George J, Button P, McCaughan GW, Crawford DH, Sievert W, Weltman MD, Cheng WS, Roberts SK. Vitamin D status does not predict sustained virologic response or fibrosis stage in chronic hepatitis C genotype 1 infection. J Hepatol. 2013;58:467-472.

23. Arteh J, Narra S, Nair S. Prevalence of vitamin D deficiency in chronic liver disease. Dig Dis Sci. 2010;55:2624-2628.

24. Fisher L, Fisher A. Vitamin $D$ and parathyroid hormone in outpatients with noncholestatic chronic liver disease. Clin Gastroenterol Hepatol. 2007;5:513-520.

25. Deluca HF, Cantorna MT. Vitamin D: its role and uses in immunology. FASEB J. 2001;15:2579-2585.

26. Chen S, Sims GP, Chen XX, Gu YY, Chen S, Lipsky PE. Modulatory effects of 1,25 dihdroxyvitamin D3 on human B cell differentiation. J Immunol. 2007;179:1634-1647.

27. El Husseiny NM, Fahmy HM, Mohamed WA, Amin $\mathrm{HH}_{\text {, }}$ Relationship between vitamin D and IL-23, IL-17 and macrophage chemoattractant protein-1 as markers of fibrosis in hepatitis C virus Egyptians. World J Hepatol. 2012;4:242-247.

28. Kitson MT, Sarrazin C, Toniutto P, Eslick GD, Roberts SK. Vitamin D level and sustained virologic response to interferon-based antiviral therapy in chronic hepatitis $\mathrm{C}$ : a systematic review and metaanalysis. J Hepatol. 2014;61:1247-1252.

29. Falleti E, Bitetto D, Fabris C, Fattovich G, Cussigh A, Cmet $S$, Ceriani E, Fornasiere E, Pasino M, leluzzi D, Pirisi M, Toniutto P. Vitamin D Binding Protein Gene Polymorphisms and Baseline Vitamin D Levels as Predictors of Antiviral Response in Chronic Hepatitis C. Hepatology. 2012;56:1641-1650.

30. Petta $S$, Ferraro D, Cammà C, Cabibi D, Di Cristina A, Di Marco V, Di Stefano R, Grimaudo S, Mazzola A, Levrero M, Scazzone C. Vitamin D levels and IL28B polymorphisms are related to rapid virological response to standard of care in genotype 1 chronic hepatitis C. Antivir Ther. 2012;17:823-831. 